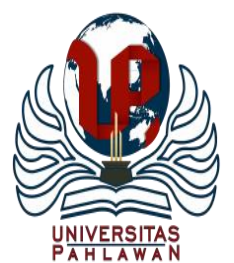

Edukatif : Jurnal Ilmu Pendidikan Volume 3 Nomor 4 Tahun 2021 Halm 1717 - 1723

EDUKATIF: JURNAL ILMU PENDIDIKAN

Research \& Learning in Education

https://edukatif.org/index.php/edukatif/index

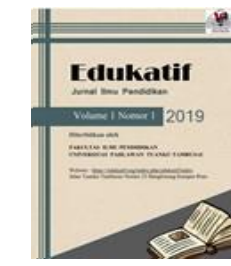

\title{
Efektivitas Pembelajaran Luring dan Daring Terhadap Hasil Belajar Tematik Siswa di Sekolah Dasar
}

\author{
Intan Karlina Sari ${ }^{1 凶}$, Suhandi Astuti ${ }^{2}$ \\ Pendidikan Guru Sekolah Dasar, Universitas Kristen Satya Wacana, Indonesia ${ }^{1,2}$ \\ E-mail : 292017024@ student.uksw.edu' ${ }^{1}$ suhandi.astuti@ uksw.edu ${ }^{2}$
}

\begin{abstract}
Abstrak
Pembelajaran daring dan luring muncul sebagai bentuk pola dalam pembelajaran di era sekarang ini sebagai akibat dari pandemi Covid-19. Penelitian eksperimen semu non-equivalent design ini bertujuan untuk mengetahui perbedaan signifikan antara pembelajaran daring dengan pembelajaran luring dilihat dari hasil belajar. Teknik yang digunakan untuk pengambilan sampel adalah jenis non probability sampling dengan teknik purposive sampling. Sampel yang dipilih dalam penelitian ini adalah siswa kelas II sekolah dasar. Instrumen pengumpulan data terdiri dari instrumen soal tes dan observasi kegiatan guru dan siswa. Nilai signifikasi normal pada uji normalitas dan terdistribusi homogen pada uji homogenitas. Hasil uji t menghasilkan thitung kelompok eksperimen 1 sebesar 5,060 dan kelompok eksperimen 2 memiliki nilai 0,000. Hal tersebut berarti bahwa hasil belajar dengan digunakannya pembelajaran secara daring lebih unggul secara signifikan dibandingkan dengan pembelajaran secara luring kelas II SD Gugus Palagan. Hasil tersebut didukung oleh ratarata nilai posttest pada pembelajaran daring yaitu 90,51 dan rata-rata nilai posttest pada pembelajaran luring yaitu 83,77.
\end{abstract}

Kata Kunci: Daring, Luring, Hasil Belajar.

\begin{abstract}
Online and offline learning emerged as a form of pattern in learning in the current era as a result of the Covid-19 pandemic. This non-equivalent design quasi-experimental research aims to determine the significant difference between online learning and offline learning in terms of learning outcomes. The technique used for sampling is non-probability sampling with purposive sampling technique. The sample selected in this study were grade II elementary school students. Data collection instruments consist of test questions and observations of teacher and student activities. Normal significance value in the normality test and homogeneously distributed in the homogeneity test. The results of the t-test resulted in the experimental group 1 having a tcount of 5.060 and the experimental group 2 having a value of 0.000. This means that the result of learning by using online learning are significantly superior to offline learning for class II SD Gugus Palagan. These results are supported by the average posttest score in online learning, which is 90.51 and the average posttest score in offline learning, which is 83.77.
\end{abstract}

Keywords: Online, Offline, Result of Learning.

Copyright (c) 2021 Intan Karlina Sari, Suhandi Astuti

$\triangle$ Corresponding author:

Email :292017024@student.uksw.edu

DOI : https://doi.org/10.31004/edukatif.v3i4.642

ISSN 2656-8063 (Media Cetak)

ISSN 2656-8071 (Media Online)

Edukatif : Jurnal Ilmu Pendidikan Vol 3 No 4 Tahun 2021 p-ISSN 2656-8063 e-ISSN 2656-8071 
1718 Efektivitas Pembelajaran Luring dan Daring Terhadap Hasil Belajar Tematik Siswa di Sekolah Dasar -Intan Karlina Sari, Suhandi Astuti

DOI: https://doi.org/10.31004/edukatif.v3i4.642

\section{PENDAHULUAN}

Pengaruh dari pandemi Covid-19 berdampak di hampir seluruh aspek kehidupan manusia dikarenakan banyak pembatasan sosial yang dilakukan oleh pemerintah untuk menekan penyebaran virus ini. Pendidikan adalah salah satu sektor yang sangat terdampak kondisi pandemi ini, terutama pendidikan sekolah dasar. (Purwanto dkk. dalam Handarini dan Wulandari, 2020). Upaya pemenuhan hak siswa untuk mendapatkan layanan pendidikan selama pandemi Covid-19 yaitu proses pembelajaran dilaksanakan melalui penyelenggaraan pembelajaran jarak jauh atau secara daring sesuai dengan Surat Edaran Menteri Pendidikan dan Kebudayaan Republik Indonesia Nomor 3 Tahun 2020 Tentang Pencegahan Corona Virus Disease (Covid-19) Pada Satuan Pendidikan (2020).

Dengan berkembangnya iptek, maka berubah pula dalam implikasi kegiatan belajar mengajar. Pemanfaatan iptek merupakan bukti perubahan dalam pembelajaran. Istilah pembelajaran dalam jaringan atau daring dan luring pun muncul sebagai bentuk pola dalam pembelajaran di era sekarang ini. Secara umum, masyarakat mengartikan bahwa daring adalah pembelajaran dengan terhubung melalui internet, sedangkan luring adalah pembelajaran tanpa internet, atau bisa dikatakan pembelajaran dengan datang secara langsung ke sekolah.

Menurut Sunendar, dkk. (2020), dalam KBBI daring adalah suatu akronim dari 2 kata yaitu dalam dan jaringan. Dikatakan daring sebab terhubung melalui internet dan media elektronik. Dilansir dari berbagai sumber, mayoritas pendidik maupun pelajar kini ramai melakukan kegiatan belajar mengajar secara daring, termasuk pada penugasan siswa. Dengan kata lain, pembelajaran daring adalah metode belajar dengan penggunaan model interaktif berbasis internet dan Learning Manajemen System (LMS). Sedangkan luring adalah sebuah akronim dari kata luar dan jaringan, atau dapat diartikan terputus dari jaringan komputer. Saat terjadinya interaksi guru dan siswa di kelas dan menggunakan buku sebagai pedoman pembelajaran, maka dinamakan luring.(Malyana, 2020).

Kurniasari et al. (2020) dalam penelitiannya tentang analisis efektivitas pelaksanaan belajar dari rumah (BDR) selama pandemi Covid-19 menyimpulkan bahwa pelaksanaan BDR berlangsung efektif untuk siswa kelas VI SD Muhammadiyah 18 Surabaya. Hasil penelitian menunjukan siswa dengan menggunakan gawainya dapat mengakses secara mandiri materi pembelajaran yang telah tersampaikan guru dan memahami materi dengan baik. Video pembelajaran juga digunakan untuk menarik minat siswa dalam menyelesaikan tahapan pembelajaran. Akan tetapi hasil berbeda dari C et al. (2020) dalam penelitiannya tentang keefektivan pembelajaran online dimasa pandemi ini menyimpulkan bahwa pembelajaran online yang telah diterapkan di SD Banyuajah 6 tidaklah cukup efektif dilakukan. Dalam penelitiannya, pendekatan induktif dengan metode penelitian kualitatif eksploratif yang digunakan.

Pembelajaran daring efektif untuk mengatasi pembelajaran yang memungkinan adanya interaksi dalam kelas virtual yang dapat diakses dimana saja dan kapan saja. Pembelajaran daring dapat melatih kemandirian dan motivasinya meningkat. Namun, kelemahan pembelajaran daring ada pada pengawasan yang kurang baik selama proses pembelajaran daring. Lemah sinyal internet dan mahalnya biaya kuota menjadi tantangan tersendiri pembelajaran daring. (Sadikin \& Hamidah, 2020)

Berpijak dari hasil penelitian terdahulu, tentang keefektivan pembelajaran daring dalam meningkatkan hasil belajar, penelitian ini dilakukan untuk membuktikan keefektivan pembelajaran daring dan luring terhadap capaian belajar melalui kegiatan penelitian yang berjudul "Efektivitas Pembelajaran Luring Dan Daring Terhadap Hasil Belajar Subtema Bermain Di Rumah Teman Kelas II Sekolah Dasar Gugus Palagan.” 
1719 Efektivitas Pembelajaran Luring dan Daring Terhadap Hasil Belajar Tematik Siswa di Sekolah Dasar -Intan Karlina Sari, Suhandi Astuti

DOI: https://doi.org/10.31004/edukatif.v3i4.642

\section{METODE PENELITIAN}

Penelitian yang dilakukan oleh peneliti adalah penelitian dengan pendekatan kuantitatif, dimana penelitian ini menekankan analisisnya pada data-data berupa angka yang kemudian diolah menggunakan metode statistika. Peneliti menggunakan desain penelitian eksperimen semu atau dikenal dengan eksperimen kuasi bentuk Non-equivalent Control Group Design. Desain eksperimen kuasi mempunyai kelompok kontrol, tetapi tidak dapat berfungsi sepenuhnya untuk mengontrol variabel-variabel luar yang memengaruhi pelaksanaan eksperimen. Bentuk Non-equivalent Control Group Design hampir sama dengan bentuk Pretestposttest Control Group Design. Perbedaan kedua bentuk desain tersebut ada pada pemilihan kelompok eksperimen 1 maupun kelompok eksperimen 2 sebelum dan sesudah diberi perlakuan. Kelompok dalam Nonequivalent Control Group Design tidak ditentukan melalui randomisasi. Desain yang digunakan peneliti bertujuan untuk melihat adanya pengaruh maupun perubahan pada kedua kelompok eksperimen (Sugiyono dalam Maya et al., 2019).

Penelitian dilakukan di kelas II SD dengan membagi kelas menjadi dua kelompok eksperimen yaitu kelompok eksperimen daring dan kelompok eksperimen luring. Penerapan kedua pembelajaran dilakukan dengan tahapan pembelajaran yang telah dirancang. Dilakukan pretest dan posttest pada setiap kelompok eksperimen guna mengetahui hasil belajar siswa. Kemudian hasil belajar tersebut akan diolah menggunakan program SPSS for Windows 21 untuk mengetahui beberapa hal seperti rata-rata, standar deviasi, nilai maksimal, serta nilai minimal baik kepada kelompok eksperimen 1 maupun kelompok eksperimen 2 pada hasil pretest dan posttest.

\section{HASIL DAN PEMBAHASAN PENELITIAN}

Dalam penelitian ini dilakukan pretest dan posttest pada masing-masing kelompok eksperimen. Hasil pengolahan statistik deskriptif kedua kelompok diolah dengan bantuan aplikasi SPSS 21.0 for windows. Berdasarkan hasil nilai pretest dan posttest pada kelas eskperimen 1 dan kelas eksperimen 2, maka hasil pengukuran akan dipaparkan dalam bentuk deskripsi komparasi berbentuk tabel dan gambar. Berikut data berupa tabel dari hasil perbedaan pada kelompok eksperimen 1 dan kelompok eksperimen 2.

Tabel 1. Komparasi Hasil Pengukuran Kelas Eksperimen 1 dan Kelas Eksperimen 2 SD Gugus Palagan

\begin{tabular}{|c|c|c|c|}
\hline Tahap & \multicolumn{2}{|c|}{ Rerata (Mean) } & Keterangan \\
\hline Pengukuran & Eksperimen 1 & Eksperimen 2 & Selisih \\
\hline Awal (Pretest) & 68,34 & 55,03 & 13,31 \\
\hline Akhir (Posttest) & 90,51 & 83,77 & 6,74 \\
\hline
\end{tabular}

Berdasarkan tabel dapat dilihat nilai rata-rata kelompok eksperimen 1 pada tahap awal sebesar 68,34 dan nilai rata-rata pada tahap akhir sebesar 90,51. Pada kelompok eksperimen 2 nilai rata-rata pada tahap awal sebesar 55,03 dan nilai rata-rata pada tahap akhir sebesar 83,77. Maka diperoleh selisih nilai rerata tahap awal pada kelompok eksperimen 1 dan kelompok eksperimen 2 sebesar 13,31. Sedangkan pada tahap akhir diperoleh selisih 6,74 pada kedua kelompok eksperimen tersebut. Berikut adalah deskripsi komparasi hasil pengukuran tersebut. 


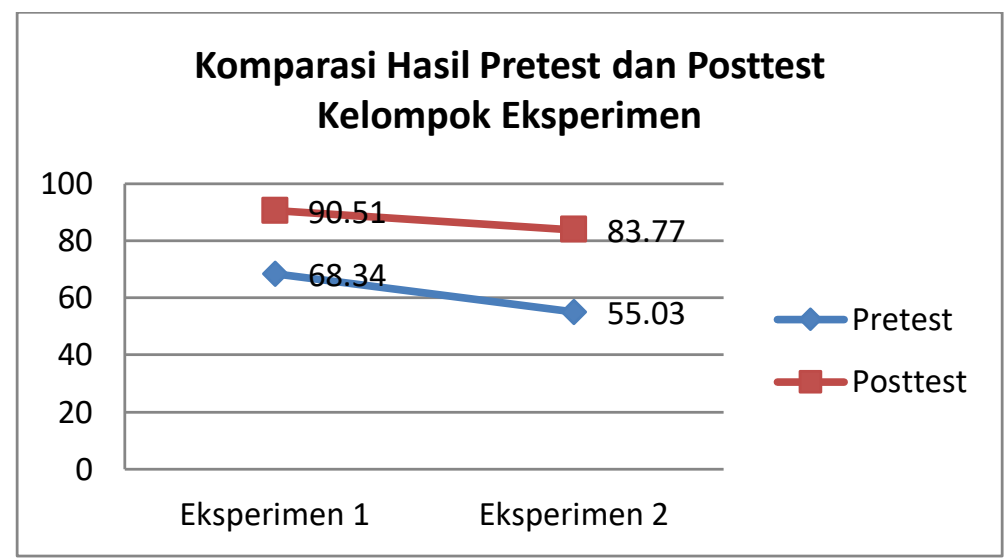

Gambar 1. Deskripsi Komparasi Skor Pretest-Posttest Kelas Eksperimen 1 dan Kelas Eksperimen 2 SD Gugus Palagan

Hasil tersebut menunjukkan bahwa pembelajaran daring memiliki hasil belajar lebih tinggi dibandingkan dengan pembelajaran luring. Namun akan dilakukan uji normalitas, uji homogenitas, dan uji t untuk dapat mendukung hasil tersebut.

Terdapat 4 faktor utama efektivitas pelaksanaan pengajaran online, yaitu 1) Kesiapan guru dalam melaksanakan pembelajaran online; 2) Penggunaan media pembelajaran online; 3) Tanggapan guru dengan sistem belajar online; dan 4) Kebermanfaatan belajar online. Hasil dari penelitiannya menunjukkan bahwa 58\% responden siap mengikuti perubahan dan mendukung arahan pemerintah untuk melaksanakan pembelajaran online, walaupun $24 \%$ responden menyatakan bahwa pembelajaran online berjalan efektif dalam meningkatkan hasil belajar siswa. (Simatupang et al., 2020).

Arifin dalam Amelia (2020: 63) menyatakan bahwa uji normalitas merupakan bagian dari uji prasyarat sebelum dilakukan analisis data yang sesungguhnya. Hasil uji normalitas nilai pretest dan posttest pada kelompok eksperimen 1 dan kelompok eksperimen 2 akan dipaparkan pada tabel di bawah ini.

Tabel 2. Hasil Uji Normalitas Skor Pretest dan Posttest Kelompok Eksperimen 1 dan Kelompok Eksperimen

2

\begin{tabular}{|c|c|c|c|c|c|c|}
\hline \multirow[t]{2}{*}{ Kelas } & \multicolumn{3}{|c|}{ Kolmogorov-Smirnov } & \multicolumn{3}{|c|}{ Shapiro-Wilk } \\
\hline & Statistic & df & Sig. & Statistic & $\mathrm{df}$ & Sig. \\
\hline $\begin{array}{l}\text { Pretest } \\
\text { Eksperimen } 1\end{array}$ &, 160 & 35 & ,024 & ,952 & 35 & 127 \\
\hline $\begin{array}{l}\text { Posttest } \\
\text { Eksperimen } 1\end{array}$ & ,165 & 35 & ,017 & ,931 & 35 & ,029 \\
\hline $\begin{array}{l}\text { Pretest } \\
\text { Eksperimen } 1\end{array}$ & ,175 & 35 & ,008 & 936 & 35 & 044 \\
\hline $\begin{array}{l}\text { Posttest } \\
\text { Eksperimen } 1\end{array}$ & ,170 & 35 & 012 & ,929 & 35 & ,027 \\
\hline
\end{tabular}

Menurut Slameto, acuan yang digunakan dalam uji normalitas adalah data dikatakan terdistribusi normal jika nilai signifikansi $>0,05$. Jika nilai signifikansi $<0,05$ maka dikatakan data tersebut tidak terdistribusi normal (Maya et al., 2019). Berdasarkan hasil uji normalitas pada tabel terlihat bahwa nilai Sig. Uji Kolmogorov-Smirnov pada nilai hasil pretest dan posttest kelompok eksperimen 1 adalah 0,24 dan 0,17. Kemudian pada hasil pretest dan posttest kelompok eksperimen 2 adalah 0,08 dan 0,12. Maka nilai signifikasi pada kelompok data yang diuji lebih besar dari 0,05 , itu berarti persebaran data pretest dan posttest pada setiap kelompok eksperimen terdistribusi normal. 
1721 Efektivitas Pembelajaran Luring dan Daring Terhadap Hasil Belajar Tematik Siswa di Sekolah Dasar -Intan Karlina Sari, Suhandi Astuti

DOI: https://doi.org/10.31004/edukatif.v3i4.642

Hasil uji homogenitas nilai pretest dan posttest kelas eksperimen 1 dan kelas eksperimen 2 akan dipaparkan dalam bentuk tabel sebagai berikut.

Tabel 3. Uji Homogenitas Pretest dan Posttest Kelas Eksperimen 1 dan Kelas Eksperimen 2

\begin{tabular}{|l|l|l|l|l|l|l|l|c|}
\hline \multirow{2}{*}{ Hasil Belajar Siswa } & \multicolumn{4}{|c|}{ Tahap Awal (Pretest) } & \multicolumn{4}{c|}{ Tahap Akhir (Posttest) } \\
\cline { 2 - 10 } & $\begin{array}{c}\text { Levene } \\
\text { Statistic }\end{array}$ & $d f 1$ & $d f 2$ & Sig. & $\begin{array}{l}\text { Levene } \\
\text { Statistic }\end{array}$ & $d f 1$ & $d f 2$ & Sig. \\
\hline Based on Mean &, 063 & 1 & 68 &, 802 &, 031 & 1 & 68 &, 861 \\
\hline Based on Median &, 005 & 1 & 68 &, 942 &, 020 & 1 & 68 &, 887 \\
\hline $\begin{array}{l}\text { Based on Median } \\
\text { and with adjusted df }\end{array}$ &, 005 & 1 & 67,902 &, 942 &, 020 & 1 & 67,984 &, 887 \\
\hline $\begin{array}{l}\text { Based } \text { on trimmed } \\
\text { mean }\end{array}$ &, 056 & 1 & 68 &, 814 &, 011 & 1 & 68 &, 917 \\
\hline
\end{tabular}

Dari uji test of homogenity of variance di atas, diketahui bahwa data nilai pretest kelompok eksperimen 1 dan kelompok eksperimen 2 memiliki varian yang sama atau homogen. Hal tersebut ditunjukkan dari angka signifikasi nilai pretest kelompok eksperimen 1 dan kelompok eksperimen 2 yaitu 0,814 lebih dari 0,05. Terdapat kriteria hasil pengujian data dengan nilai signifikasi lebih besar dari 0,05 maka varian dari dua atau lebih kelompok data adalah homogen. Namun, jika signifikasi lebih kecil dari 0,05 berarti data tidak homogen. Kemudian hasil uji homogenitas posttest pada kedua kelas eksperimen menunjukkan nilai signifikasi atau probabilitas sebesar 0,887 lebih besar dari 0,05, yang berarti data pada kedua kelompok kelas eksperimen dinyatakan bervarian sama.

Setelah melaksanakan uji normalitas dan uji homogenitas maka dilaksanakan uji t atau uji beda untuk melihat perbandingan rata-rata yang signifikan terdapat hasil belajar kelompok eksperimen 1 maupun kelompok eksperimen 2. Hasil uji t atau uji beda menggunakan uji Independent T-Test dapat dilihat pada tabel berikut.

Tabel 4. Hasil Uji Independent Sample T-Test Posttest Kelas Eksperimen 1 dan Kelas Eksperimen 2

\begin{tabular}{|c|c|c|c|c|c|c|c|c|c|c|}
\hline & \multicolumn{2}{|c|}{$\begin{array}{l}\text { Levene's } \\
\text { Test for } \\
\text { Equality of } \\
\text { Variances }\end{array}$} & \multicolumn{7}{|c|}{ t-test for Equality of Means } \\
\hline & & \multirow[t]{2}{*}{$\mathrm{F}$} & \multirow[t]{2}{*}{ Sig. } & \multirow[t]{2}{*}{$\mathrm{T}$} & \multirow[t]{2}{*}{$\mathrm{df}$} & \multirow[t]{2}{*}{$\begin{array}{l}\text { Sig. } \\
(2- \\
\text { taile } \\
d)\end{array}$} & \multirow[t]{2}{*}{$\begin{array}{c}\text { Mean } \\
\text { Difference }\end{array}$} & \multirow[t]{2}{*}{$\begin{array}{l}\text { Std. Error } \\
\text { Differenc } \\
\text { e }\end{array}$} & \multicolumn{2}{|c|}{$\begin{array}{c}95 \% \\
\text { Confidence } \\
\text { Interval of the } \\
\text { Difference }\end{array}$} \\
\hline & & & & & & & & & $\begin{array}{c}\text { Lowe } \\
\mathrm{r}\end{array}$ & Upper \\
\hline \multirow[t]{2}{*}{$\begin{array}{l}\text { Hasil } \\
\text { Belaja } \\
\mathrm{r} \\
\text { Siswa }\end{array}$} & $\begin{array}{l}\text { Equal } \\
\text { variance } \\
\text { s } \\
\text { assumed }\end{array}$ & $\begin{array}{r}, 03 \\
1\end{array}$ & $\begin{array}{r}, 86 \\
1\end{array}$ & $\begin{array}{r}5,06 \\
0\end{array}$ & 68 & ,000 & 6,743 & 1,333 & 4,084 & 9,402 \\
\hline & $\begin{array}{l}\text { Equal } \\
\text { variance } \\
\text { s not } \\
\text { assumed }\end{array}$ & & & $\begin{array}{r}5,06 \\
0\end{array}$ & $\begin{array}{r}67,76 \\
9\end{array}$ & ,000 & 6,743 & 1,333 & 4,084 & 9,402 \\
\hline
\end{tabular}

Berdasarkan tabel diperoleh thitung sebesar 5,060. Hasil analisis uji t atau uji beda dengan menggunakan asumsi $t$-test for equality of means dengan Sig.2-tailed kelompok eksperimen 1 maupun kelompok 2 sebesar 0,000. Oleh karena nilai signifikasi 2-tailed kedua kelas lebih kecil dari 0,05, maka dapat disimpulkan bahwa 
$\mathrm{H}_{0}$ ditolak dan $\mathrm{H}_{\mathrm{a}}$ diterima yang berarti bahwa hasil belajar menggunakan pembelajaran secara daring lebih unggul secara signifikan dibandingkan dengan pembelajaran secara luring.

N. et al. (2019) dengan penelitiannya yang berjudul Pengaruh Daring Learning terhadap Hasil Belajar IPA Siswa Sekolah Dasar, juga menunjukkan bahwa pembelajaran berbasis Daring Learning yang menggunakan aplikasi edmodo berdampak yang sangat positif bagi siswa. Data menunjukkan nilai mean pada kelompok eksperimen 89,62 dan pada kelompok kontrol 80,77, dengan selisih 8,85. Hasil analisis dengan mann whitney memiliki $p$ value $0,000<0,05$ yang dapat diartikan terdapat pengaruh Daring Learning terhadap hasil belajar mata pelajaran IPA, dan adanya perbedaan yang signifikan antara pembelajaran Daring Learning dengan edmodo dan pembelajaran konvensional.

Penelitian lain yang sejalan dan mampu mendukung hasil penelitian peneliti adalah Dewi (2020) dalam penelitian tentang dampak covid-19 terhadap implementasi pembelajaran daring di sekolah dasar menunjukkan bahwa kegiatan pembelajaran daring dapat berjalan efektif dan baik tergantung dari kreativitas guru dalam mengelola pembelajaran secara online. Bukan hanya guru, tetapi kerjasama yang baik dari orang tua dalam membimbing siswa dalam pembelajaran online juga dapat menjadikan pembelajaran daring efektif.

Terdapat perbedaan hasil belajar antara siswa yang diajarkan pembelajaran blended learning dibandingkan siswa yang diajarkan pembelajaran konvensional. Dikarenakan meningkatnya motivasi belajar siswa akibat penerapan pembelajaran blended learning, maka terdapat pula peningkatan hasil belajar siswa akibat penerapan pembelajaran blended learning. (Sjukur, 2012).

Penelitian yang dilakukan telah berjalan sesuai dengan perencanaan, akan tetapi masih terdapat keterbatasan dalam penelitian yaitu pada hasil belajar siswa. Pada dasarnya hasil belajar siswa mencakup tiga ranah yaitu sikap, pengetahuan, dan keterampilan. Namun dalam penelitian ini hanya dapat mengukur hasil belajar pada ranah pengetahuan saya.

\section{KESIMPULAN}

Berdasarkan paparan penelitian dan hasil analisis yang dilakukan pada bab sebelumnya, dapat disimpulan bahwa dalam hasil belajar kelas II pada tema 2 Bermain di Lingkungan ku subtema 2 Bermain di Rumah Teman SD Gugus Palagan dengan pembelajaran tematik secara daring lebih efektif atau unggul secara signifikan dibandingkan dengan pembelajaran tematik secara luring. Hal tersebut berdasarkan uji beda ratarata hasil belajar posttest (t-test) dalam penerapan model pembelajaran daring sebagai kelompok eksperimen 1 dan model pembelajaran secara luring sebagai kelompok eksperimen 2. Hasil uji t nilai posttest menunjukkan signifikasi (2-tailed) pada tiap kelompok eksperimen sebesar 0,000. Sehingga dapat disimpulkan bahwa $\mathrm{H}_{0}$ tidak diterima dan menerima $\mathrm{H}_{\mathrm{a}}$ yang berarti bahwa hasil belajar dengan digunakannya pembelajaran secara daring lebih unggul secara signifikan dibandingkan dengan pembelajaran secara luring pada tema 2 Bermain di Lingkunganku subtema 2 Bermain di Rumah Teman kelas II SD Gugus Palagan.

Guru diharapkan dapat memahami mendalam tentang pembelajaran tematik, sehingga dapat mengelola pembelajaran tematik luring maupun pembelajaran daring sesuai dengan perkembangan kognitif dan kemajuan jaman pada lingkungan. Menambah pandangan luas dalam mengajar dari segi kreativitas dan inovasi pembelajaran yang menarik.

\section{DAFTAR PUSTAKA}

Amelia, K. (2020). Efektivitas Penerapan Model Pembelajaran Discovery Learning dan Inquiry terhadap Keterampilan Berpikir Kritis Subtema Perubahan Bentuk Energi Kelas III SD Gugus Sudirman. Universitas Kristen Satya Wacana.

C, B. D., Amelia, A., Hasanah, U., \& Putra, A. M. (2020). Analisis Keefektifan Pembelajaran Online di Masa 
1723 Efektivitas Pembelajaran Luring dan Daring Terhadap Hasil Belajar Tematik Siswa di Sekolah Dasar -Intan Karlina Sari, Suhandi Astuti

DOI: https://doi.org/10.31004/edukatif.v3i4.642

Pandemi Covid-19. Mahaguru : Jurnal Pendidikan Guru Sekolah Dasar, 2(1), 28-37.

Dewi, W. A. F. (2020). DAMPAK COVID-19 TERHADAP IMPLEMENTASI PEMBELAJARAN DARING DI. 2(1), 55-61. https://edukatif.org/index.php/edukatif/index\%0ADAMPAK

Handarini, O. I., \& Wulandari, S. S. (2020). Pembelajaran Daring Sebagai Upaya Study From Home ( SFH ) Selama Pandemi Covid 19 Pembelajaran Daring Sebagai Upaya Study From Home ( SFH ) ... .. Jurnal Pendidikan Administrasi Perkantoran, 8(1), 496-503. https://journal.unesa.ac.id?index.php/jpap

Kurniasari, A., Pribowo, F. S. P., \& Putra, D. A. (2020). Analisis Efektivitas Pelaksanaan Belajar dari Rumah (BDR) Selama Pandemi Covid-19. Jurnal Review Pendidikan Dasar: Jurnal Kajian Pendidikan Dan Hasil Penelitian, 6(3). http://journal.unesa.ac.id/index.php/PD

Surat Edaran Menteri Pendidikan dan Kebudayaan Republik Indonesia Nomor 3 Tahun 2020 Tentang Pencegahan Corona Virus Disease (Covid-19) Pada Satuan Pendidikan, 11 (2020).

Malyana, A. (2020). Pelaksanaan Pembelajaran Daring dan Luring Dengan Metode Bimbingan Berkelanjutan pada Guru Sekolah Dasar di Teluk Betung Utara Bandar Lampung. Pedagogia: Jurnal Ilmiah Pendidikan Dasar Indonesia, 2(1), 67-76. http://jurnal.stkippgribl.ac.id/index.php/pedagogia

Maya, A., Widiastuti, K., \& Astuti, S. (2019). Keefektivan Pembelajaran Tematik Berbasis Lingkungan dengan Pembelajaran Tematik Buku Guru dan Siswa Terhadap Hasil Belajar Siswa Kelas 4 SD Gugus Gedong Songo. Efektor, 6(1), 68-76. https://doi.org/https://doi.org/10.29407/e.v6i1.12780

N., S. A., Bayu, Rani, \& S., M. (2019). Pengaruh Daring Learning terhadap Hasil Belajar IPA Siswa Sekolah Dasar. Prosiding: Seminar Nasional Sains Dan Enterpreneurship VI Tahun 2019, 1(1), 1-5.

Sadikin, A., \& Hamidah, A. (2020). Pembelajaran Daring di Tengah Wabah Covid-19 ( Online Learning in the Middle of the Covid-19 Pandemic ). Biodik: Jurnal Ilmiah Pendidikan Biologi, 6(1), 214-224. https://online-journal.unja.ac.id/biodik Research

Simatupang, N. I., Rejeki, S., Sitohang, I., Patricia, A., \& Simatupang, I. M. (2020). Efektivitas Pelaksanaan Pengajaran Online pada Masa Pandemi Covid-19 Dengan Metode Survey Sederhana. Jurnal Dinamika Pendidikan, 13(2), 197-203. https://doi.org/10.33541/jdp.v13i2.1754

Sjukur, S. B. (2012). Pengaruh Blended Learning Terhadap Motivasi Belajar dan Hasil Belajar SIswa Tingkat SMK. Jurnal Pendidikan Vokasi, 2(November 2012), 368-378. https://journal.uny.ac.id?index.php/ 